\title{
The Philosophy of Political History in Oakeshott and Collingwood
}

\author{
James Alexander \\ Dept. of Political Science, Bilkent University, Ankara \\ jalexand@bilkent.edu.tr
}

\begin{abstract}
Every political philosopher has a philosophy of political history, if sometimes not a very good one. Oakeshott and Collingwood are two twentieth century political philosophers who were particularly concerned with the significance of history for political philosophy; and who both, in the 1940s, sketched what I call philosophies of political history: that is, systematic schemes which could make sense of the entire history of political philosophy. In this article I observe that Oakeshott depended for the political threefold sketched in his Introduction to Hobbes's Leviathan on a threefold Collingwood had developed in relation to science in The Idea of Nature. This is, I think, a novel observation. I contrast this political threefold with Collingwood's own political threefold in The New Leviathan. I then consider the neglect of these schemes, along with the rare attempts to defend such philosophies of history in the writings of Greenleaf and Boucher. My own claim is that these philosophies of political history are exemplary: and that the threefold is, for obvious Hegelian reasons, a still useful form for this sort of reflection. Political philosophy is likely to improve the more it takes the philosophy of political history seriously.
\end{abstract}

\section{Keywords}

philosophy - politics - history - Oakeshott - Collingwood

This is a contribution to something I would like to call the philosophy of political history, that is, a contribution to the philosophy of history in relation to political philosophy. It begins by explicating a rather obscure, though I think 
reasonably well known, passage in Oakeshott's introduction to his edition of Hobbes's Leviathan, first published in 1946 (also later published in Hobbes on Civil Association and the 1991 edition of Rationalism in Politics). ${ }^{1}$ It goes on to show how the threefold Oakeshott sketched in some brevity and one might say obscurity is wholly indebted to the account of the history of the philosophy of nature which Collingwood developed in his Idea of Nature, published in 1945. Collingwood's purpose was wholly to explain something about the history of the philosophy of the natural sciences, which he supposed had moved through three stages. Oakeshott, who was less given to the philosophy of history than Collingwood $^{2}$ - that is to say, was less inclined to impose the structures of his thought on history and more inclined to find the shapes of his thoughts in history - did not say that these were three stages, but said instead that they were three traditions, rival traditions, which had of course emerged at particular times. The novelty in Oakeshott was to take Collingwood's threefold division of the stages of the history of the philosophy of nature and apply it to the traditions of the history of political philosophy. This was to put forward a philosophy of political history: not one which took Hegelian or even Collingwoodian form, in terms of stages, but one which attempted to respect the history of political philosophy in such a way that justice could be done not only to what had been thought in the past but what ought to be thought now

1 Michael Oakeshott, Introduction, in Hobbes Leviathan (Oxford: Basil Blackwell, 1946), pp. vii-lxvi, also in Michael Oakeshott, Hobbes on Civil Association originally published in 1975 (Indianapolis: Liberty Fund, 200o), pp. 1-79, Michael Oakeshott, Rationalism in Politics and Other Essays ed. Timothy Fuller (Indianapolis: Liberty Fund, 1991), pp. 221-94.

2 I cannot go far into Oakeshott's or Collingwood's views about the philosophy of history here. In short, in the 1920s Collingwood argued that the philosophy of history was a confusing term because it had been used firstly for discovering laws in history and secondly for seeing history as the working out of a plan. The first, he thought, was a mistake; the second not: seeing history in terms of a plot was not the 'philosophy of history', he argued, but, simply, 'history'. So 'the philosophy of history' was for Collingwood merely the philosophical consideration of the historical attempt to discover truth. Collingwood, 'The Nature and Aims of a Philosophy of History', Proceedings of the Aristotelian Society, 25 (1924-25), pp. 151-174, at pp. 155 \& 161. Oakeshott agreed, and was even more emphatic about this. See Michael Oakeshott, What is History? and other Essays ed. Luke O'Sullivan (Exeter: Imprint Academic, 2004), pp. 117-32 \& 201-06. This is all very well, but, clearly there is history and there is history. Most of what passes for history nowadays is not 'seeing history as the working out of a plan': so I think we can restore the term the 'philosophy of history' for history as the working out of stages or traditions - which would mean that Collingwood and Oakeshott were both, though they would not have admitted it, philosophers of history. 
in the present - a present complicated by the fact that we are so concerned to know what was thought in the past and understand it as belonging to the past.

At one level this is a scholarly point. But this article is written for the reason that I think all political philosophers and even historians of political philosophy have silent philosophies of political history of one sort or another, sometimes not very good ones, and that it is the duty of anyone engaged in the serious study of political philosophy to bring such philosophies of political history to consciousness. I myself was educated at Cambridge by historians eminently, Cowling, Dunn, Skinner, Tuck, Pagden, Hont, Runciman - and have spent much time reflecting on the status of the history of political thought. But I do not think that the 'Cambridge School' - such as it is - has ever managed to explain satisfactorily why history matters as much as it is supposed to matter. By returning history to the philosophy of history I intend to indicate one reason why it does. There is not much to be derived from the history of political philosophy if we simply study fragments of it in miniature in order to irrelevantly decorate our current preoccupations.

To make it absolutely clear what I am doing in this paper, the sections are as follows:

I Oakeshott's paragraph on three political traditions from 'Introduction to Leviathan' (1946).

II How this is indebted to Collingwood's three views of science from The Idea of Nature (1945).

III Oakeshott's apparent abandonment of the political threefold except for a few references in his Lectures (1966-67).

IV The oddity of Collingwood's alternative threefold philosophy of political history in New Leviathan (1942).

V Conclusion: how we have to try to make sense of the philosophy of political history before we make sense of political philosophy.

It should become clear that, apart from a few attempts by Greenleaf and Boucher, not much has been done along the lines sketched by Collingwood and Oakeshott. This is not least because the sketches were different. But even if we admit the discordances, I think we should consider whether sketches like these are the only way to make the study of political history properly philosophical and the only way to prevent works about the history of political thought simply lapsing into mere chronicles of things that were thought. 

'Introduction to Leviathan' (1946)

In the introduction to Leviathan, Oakeshott wrote a paragraph, which I quote at length so that his exact formulations may be read in full. I cannot be the only reader of this passage who has been at once overwhelmed by Oakeshott's apparent achievement in summing up the entire history of political philosophy and perplexed by his apparent disdain for explaining what he writes, if he came up with it himself, where he got it from, if he did not, and the reason for it. The style is about as ex cathedra as can be found in the writing of any twentieth-century political philosopher - even if the first word is a conditional 'If'. (The conditionality of that 'If' soon seems to be lost.)

If the unity of the history of political philosophy lies in a pervading sense of human life as a predicament and in the continuous reflection of the changing climate of the European intellectual scene, its significant variety will be found in three great traditions of thought. The singularities of political philosophies (like most singularities) are not unique, but follow one of three main patterns which philosophical reflection about politics has impressed on the intellectual history of Europe. These I call traditions because it belongs to the nature of a tradition to tolerate and unite an internal variety, not insisting upon conformity to a single character, and because, further, it has the ability to change without losing its identity. The first of these traditions is distinguished by the master-conceptions of Reason and Nature. It is coeval with our civilisation; it has an unbroken history into the modern world; and it has survived by a matchless power of adaptability all the changes of the European consciousness. The master-conceptions of the second are Will and Artifice. It too springs from the soil of Greece, and has drawn inspiration from many sources, not least from Israel and Islam. The third tradition is of later birth, not appearing until the eighteenth century. The cosmology it reflects in its still unsettled surface is the world seen on the analogy of human history. Its master-conception is the Rational Will, and its followers may be excused the belief that in it the truths of the first two traditions are fulfilled and their errors find a happy release. The masterpiece of political philosophy has for its context, not only the history of political philosophy as the elucidation of the predicament and deliverance of mankind, but also, normally, a particular tradition in that history; generally speaking it is the supreme expression of its own tradition. And, as Plato's Republic 
might be chosen as the representative of the first tradition, and Hegel's Philosophie des Rechts of the third, so Leviathan is the head and crown of the second. ${ }^{3}$

Without the mention of these three representative texts at the end of the paragraph I think the reader would be wholly lost. Mention of them lends authority to what Oakeshott is saying. Plato's Republic, Hobbes's Leviathan, Hegel's Philosophy of Right: it is hard to think of three greater achievements in the history of political philosophy. Aristotle's Politics has an undoubted claim. But Rousseau's Social Contract falls a bit short, as do less complete works like Machiavelli's Prince, Marx's Communist Manifesto, Mill's On Liberty, though they are all highly suggestive. Even the other great works of political philosophy which I happen to admire - modern ones, like Oakeshott's On Human Conduct, Collingwood's New Leviathan, Schmitt's Concept of the Political - are either, in the case of Schmitt, a brilliant insight into one element of politics or, in the cases of Oakeshott and Collingwood, compilations of brilliant suggestions offered in elucidation of earlier writings and brought into some sort of incomplete system: they are all, indeed, indebted to the tradition of writing which runs from Plato to Hegel. (The fact that they are indebted in exactly this way is what, I hope the following observations will show, makes them modern.)

But to return to Oakeshott's passage. This passage is frequently quoted by Oakeshott scholars but hardly ever subject to critical consideration. ${ }^{4}$ What we have here if we ignore the reference to the three great writings is the suggestion that there are three traditions. Oakeshott has awkward names for them:

3 Oakeshott, 'Introduction', pp. xi-xii (also found in Oakeshott, Hobbes on Civil Association, pp. 7-8, and Rationalism in Politics, pp. 227-8).

4 See, for instance, Roy Tseng, The Sceptical Idealist: Michael Oakeshott as a Critic of the Enlightenment (Exeter: Imprint Academic, 2003), p. 191, and Kenneth McIntyre, The Limits of Political Theory: Oakeshott's Philosophy of Civil Association (Exeter: Imprint Academic, 2004), pp. 144-5 for a lack of criticism. Sometimes there is error, as when we are told that Oakeshott's threefold is an account of three 'stages' rather than of three 'traditions' (as in The Cambridge Companion to Michael Oakeshott, p. 226). The only detailed consideration and use of the threefold is by David Boucher (about which see below). Most scholars of Oakeshott do not know what to make of the threefold. Ian Tregenza comments that Oakeshott 'never fills in the detail of this history in the way Hegel, or indeed, Collingwood does'. See Michael Oakeshott on Hobbes: A Study in the Renewal of Philosophical Ideas (Exeter: Imprint Academic, 2003), p. 13. Paul Franco goes even further: 'What exactly this means or involves is not yet clear.' The Political Philosophy of Michael Oakeshott (New Haven: Yale University Press, 1990), p. 88. 
1. Reason and Nature.

2. Will and Artifice.

3. Rational Will.

Despite the capital letters, he could have hardly have chosen worse names: they are neither memorable nor revealing. (There is good reason to think that the name of anything should be either memorable or revealing). They tell us almost nothing in themselves, and Oakeshott's explanation of each is minimal to a fault. It is only when he comes to the third tradition that he uses the word which gives us the clue to unravel his meaning, and also adds a mordant comment which makes it clear that he does not think that the history of political philosophy should be coerced into anything like a simple philosophy of political history. To deal with the second of these points first, he says:

Its followers may be excused the belief that in it the truths of the first two traditions are fulfilled and their errors find a happy release.

This is, I think, a clear, if delicate, rebuttal of any Hegelian conviction that the third tradition amounts to a third stage which sublates - negates, assimilates and transforms - the first and second forms into a higher and harmonious form. Whatever Oakeshott is doing here (and I am surprised to see just how many commentators quote this, without noting the evident irony, and go on to say that Oakeshott himself was sanctioning the idea of reconciliation in the third), ${ }^{5}$ it is not sanctioning any historical achievement. The arrival of Hegel, Oakeshott means to say, did not make it unnecessary to read Plato and Hobbes. On the contrary: the entire history remains alive in our consciousness: it remains a hinterland of contradictory visions which we may always explore to our benefit.

When I say that he uses a word which enables us to unravel his meaning, it is one of the quieter words in this passage. It is the word 'analogy'. This word alone should be enough to dispel any doubt that Oakeshott was in this passage indebted to Collingwood's Idea of Nature. But what we have to note is that there is not only an analogy which helps us make sense of the third tradition; there are also analogies which help us make sense of the first and second.

5 See, for instance, some of the contributors (Boucher and Podoksik) in The Cambridge Companion to Michael Oakeshott ed. Efraim Podoksik (Cambridge: Cambridge University Press, 2012), pp. 250 \& 287-8. 


\section{How This Is Indebted to Collingwood's Three Views of Science from The Idea of Nature (1945)}

Collingwood's Idea of Nature, is, as the title suggests, a contribution to the history of philosophy of science rather than the history of the philosophy of politics. Collingwood made a late contribution to political philosophy - including some reflections on its history, which we shall consider below - in The New Leviathan, published in 1942. That was the last work published in his lifetime. On his death in 1943, there were several manuscripts ready for publication. T.M. Knox published The Idea of Nature in 1945 and The Idea of History in $1946 .{ }^{6}$ Collingwood's reputation is still so much tied to The Idea of History, along with The Autobiography of 1939, that it is sometimes hard to convince anyone that these works are considerably less interesting than the early system, Speculum Mentis of 1924, the two great original works of philosophy, An Essay on Philosophical Method of 1933 and An Essay on Metaphysics of 1940, or even The Idea of Nature, which, if anything, shows a grasp of complexity (as well a determination to understand matters remote from his own interests) which makes it a greater achievement than the historical writings.

Unlike The Idea of History which simply considers a series of historians in succession, The Idea of Nature proposes an architectonic view of the history of science, or, more properly, the understanding of nature. There is no indication in this book that Collingwood recognised that his ideas could be applied to the history of politics, though they obviously could be so applied. As we shall see there is some evidence of this scheme in The New Leviathan, though nothing quite as arresting as Oakeshott's short utterance. So let us consider the argument about science. Whereas Oakeshott rather cautiously wrote of 'traditions', Collingwood more simply wrote as if the shifts in viewpoint were collective and enabled us to distinguish stages in history. He wrote of 'three periods of constructive cosmological thinking,, ${ }^{7}$ which he distinguished as 'The Greek View of Nature', 'The Renaissance View of Nature' and 'The Modern View of Nature. He did not suppose that the entire history of thought could be fitted into this structure, but he certainly thought he was discussing the only developments of any significance in the European tradition. Indeed, the entire structure of his book was intended to indicate that with each transition philosophers had moved from one way of thinking to another. This should not be

6 For the composition of The Idea of Nature between 1933 and 1939 see David Boucher, 'The Principles of History and the Cosmological Conclusion to The Idea of Nature', Collingwood and British Idealism Studies 2 (1995), pp. 140-74, at p. 146.

7 R.G. Collingwood, The Idea of Nature (Oxford: Clarendon Press, 1945), p. 1. 
forgotten: whereas Collingwood tended to favour accounts of historical stages of the sort familiar from a Hegelian type of philosophy of history (and elsewhere, in Speculum Mentis, conceptual stages of the sort familiar from Hegel's other writings), Oakeshott's dialectic was subtler. It contemplated not a simple succession of stages, but tortured entanglements of tradition. (Collingwood's was of course a shorthand, and we do not need to be too critical of it: the point is more to recognise that Oakeshott was clearly critical about it: he never allowed himself to write as if there were stages in history.)

In The Idea of Nature, Collingwood argued that at certain critical points in the past there was a ruling analogy which enabled men to explain nature. The first was that of the Greeks, who had assumed that 'the world of nature is saturated or permeated by mind', so that mind and matter are indistinguishable, and so the laws by which the world orders itself are its own. ${ }^{8}$ The second was that of the Renaissance (a convenient term, by which he mostly meant not the fourteenth or fifteenth centuries but the sixteenth and seventeenth), in which, on the contrary, it was assumed that 'the natural world is a machine', so that mind and matter are distinguished, and laws are imposed on nature from outside, by a creator. ' 'The Renaissance thinkers, like the Greeks, saw in the orderliness of the natural world an expression of intelligence; but for the Greeks this intelligence was nature's own intelligence, for the Renaissance thinkers it was the intelligence of something other than nature: the divine creator and ruler of nature. 10 Collingwood supposed that this was in a sense part of the long legacy of the Christian incarnation of word in the world. The third view was that of the Moderns. Initially, when writing of the first and second views, Collingwood did not mention the word analogy, but when he summarised them as he approached the third view it is clear that each view depended on an analogy. Again, I quote at length to establish the point: ${ }^{11}$

\footnotetext{
$8 \quad$ Ibid., p. 3.

$9 \quad$ Ibid., pp. 4-5.

$10 \quad$ Ibid., p. 5 .

11 I also quote Collingwood here to avoid falling into the trap many Collingwood and Oakeshott scholars fall into which is of engaging in exposition in the form of paraphrase. This seems to be a stage Oakeshott and Collingwood scholarship is going through. Perhaps, if knowledge of their writings cannot be taken for granted, then exposition through paraphrase is necessary or useful: but it enables the scholars to be rather uncritical at times, since it becomes hard for the uninitiated reader to distinguish the exposition of the original literature from the criticism of it. This, no doubt, is because most Oakeshott and Collingwood scholars continue - with good reason - to be partisan for Oakeshott and Collingwood. This is a case where usually one can trust a man's enemies better than his friends. Even the most subtle partisan is susceptible to this doubt: that he
} 
The Greek view of nature as an intelligent organism was based on an analogy: an analogy between the world of nature and the individual human being, who begins by finding certain characteristics in himself as an individual, and goes on to think of nature as possessed of similar characteristics... The Renaissance view of nature as a machine is equally analogical in origin, but it presupposes a quite different order of ideas. First, it is based on the Christian idea of a creative and omnipotent God. [At this point, we may well recall Oakeshott's rather more mordant and even modern 'Israel and Islam'.] Secondly, it is based on the human experience of designing and constructing machines... It was an easy step to the proposition: as a clockmaker or millwright is to a clock or mill, so is God to Nature. ${ }^{12}$

He continued:

Modern cosmology, like its predecessors, is based on an analogy. As Greek natural science was based on the analogy between the macrocosm nature and the microcosm man, as man is revealed to himself in his own self-consciousness; as Renaissance natural science was based on the analogy between nature as God's handiwork and the machines that are the handiwork of man ...; so the modern view of nature, which first begins to find expression towards the end of the eighteenth century and ever since then has been gathering weight and establishing itself more securely down to the present day, is based on the analogy between the processes of the natural world as studied by natural scientists and the vicissitudes of human affairs as studied by historians. ${ }^{13}$

This particular analogy was only possible once history was established as a fundamental category of thought, which, Collingwood said - a point no one would now argue with - was in the eighteenth century. ${ }^{14}$ He suggested that scientists began to recognise that objects continually change. (Darwin, is of course, exemplary here: but the recognition was everywhere: in Hegel, Comte, Lyell, Marx and countless others.) Collingwood went on in the following pages to explore the consequences of this point of view (the view that change was no

is a friend, and therefore not an entirely honest commentator, and in a sense worse than an enemy, whose dishonesty is easier to discern.

12 Ibid., pp. 8-9.

13 Ibid., p. 9 .

14 Ibid., p. 10. 
longer cyclical but progressive, the view that nature was no longer mechanical but organic, and so on). But we may leave The Idea of Nature here. The rest of the book was Collingwood's determined driving of these three ideas through the history of the philosophy of science from Plato to Whitehead.

Let me summarise the scheme:

1. The Greek View of Nature: founded on the Analogy of Man the Microcosm and Nature the Macrocosm.

2. The Renaissance View of Nature: founded on the Analogy of Man the Creator and God the Creator.

3. The Modern View of Nature: founded on the Analogy of Human History and Natural History.

Oakeshott was clearly indebted to Collingwood. For just as Collingwood wrote of 'the analogy between the processes of the natural world as studied by natural scientists and the vicissitudes of human affairs as studied by historians', so Oakeshott wrote of 'the world seen on the analogy of human history.'

Collingwood's set of analogies enables us to explain Oakeshott's otherwise obscure threefold. 'Reason and Nature' alludes to the fact that reason and nature are bound together through the analogy of macrocosm and microcosm. Man is, as Aristotle said, zoon politikon, a political animal. The state, therefore, is natural. 'Will and Artifice' alludes to the fact that there is an analogy between God's will and man's will: so that human creations are artificial, not natural. The state, therefore, is artificial. And 'Rational Will'? This was clumsy. I think Oakeshott should have called the third tradition something else, if he had to insist on these sorts of terms. 'History and Change' or something equally bland would have done: something which emphasised the distinctively historical element. By calling it 'Rational Will' he tied it rather too tightly to some sort of Hegelian succession: which is ironic, since Oakeshott generally wanted to avoid such a succession. But the third tradition is broader than that. We all, as Collingwood rightly suggested, and not only Hegelians, have come to think this way. The point is that historical consciousness does not eliminate everything which comes before, but it complicates it almightily - as everyone knows who has read or reflected on the works of Nietzsche, Gadamer, Koselleck or MacIntyre or, indeed, Collingwood and Oakeshott. 


\section{Oakeshott's Apparent Abandonment of the Political Threefold Except for a Few References in His Lectures (1966-67)}

Oakeshott delivered lectures on the history of political thought throughout his life. In the lectures from 1966-67 which have recently been published he said that there are (or have been) three ways of conceptualising the state:

1. Natural: so that a 'state' is a 'natural community'; or

2. Artificial: so that a 'state' is an artificial community; or

3. Neither natural nor artificial, strictly speaking, but something that partakes of both: so that a state is a 'historic' bond.15

Oakeshott commented that Aristotle, Bodin, Filmer and Montesquieu, among others, theorised the first (though even Hobbes had used the analogy of the state as a 'body');16 Hobbes, Locke and Rousseau, the second; and Hume, Burke and Hegel, among others, the third. It should be noted here that Oakeshott called these three 'interpretations': and, again, without saying so explicitly, was refusing to allow that the three should be considered successive stages. On the contrary, he emphasised that the second interpretation had ancient origins, and was manifest in the distinction of the divine and the human in Christianity, though it came to consciousness in the seventeenth century. However, when it did come to consciousness, 'the intellectual disposition it reflected was the assumption that everything in the world is either "natural" or "artificial".'17 For those who accepted that the state was artificial, the state was the 'product of an act of association'. 18 The third interpretation is 'more difficult to describe': 'it represents a breakout from the intellectual disposition which assumes that everything in the world must be either "natural" or "artificial". ${ }^{19}$ The historical state is not natural because it is contingent, and it is not artificial because it is not made for a purpose. (Oakeshott mentions that according to the second interpretation, the state is made for a purpose, whether the subordination of

15 Michael Oakeshott, Lectures in the History of Political Thought (Exeter: Imprint Academic, 2006), p. 404. See pp. 404-25 for the entire discussion. David Boucher, whose paper I discuss below, notes the moments when Oakeshott uses the triad in his writings, especially the lectures, but appears to have missed this decisive passage on p. 404. See 'Oakeshott and the History of Political Thought', Collingwood and British Idealism Studies 13 (2007). pp. 69-101.

16 Oakeshott, Lectures in the History of Political Thought, p. 405.

17 Ibid., p. 412.

18 Ibid., p. 416.

19 Ibid., p. 421. 
passion to reason, as in Rousseau, moral progress, as in Mill, or peace, as in Hobbes. $)^{20}$ The state, according to this interpretation, is 'forged by time and circumstance'. Here he mentions Ferguson, Hume, Coleridge, Vico, Herder, Savigny and Hegel, but especially Burke.

If we were to try to make sense of these three ideas of the state, then we could say that we have firstly the idea that the state exists because whatever does exist is a dim groping towards the true state. This is a view of the state as an end in the sense of a telos. Secondly, we have the idea that the state exists when and only when we consciously imagine it and artificially establish it: the state is not a telos, but something which emerges out of human activity. And thirdly, we have the idea that the state exists neither because it is necessary nor because we have established it but because we have come to have some sort of consciousness about its contingent emergence in our history. Oakeshott would probably say that all these are thinkable views of the state. The third is the eminently modern way of thinking. It is not a Hegelian reconciliation of the first two: it is a 'third way': but nonetheless it is possible to admit that it includes the first two within itself. This should be a platitude to anyone who reflects on the nature of historical understanding: for something like the state, in terms of historical understanding, includes whatever we have understood the state to be in history: which means not only the ideas of the state which are themselves historical in content, but earlier, unhistorical, ideas of the state.

It seems to me that this is a good way of thinking about the state. It is in terms of what we could call an unresolved or open dialectic.

I should perhaps draw attention to the fact that the only scholar to have written about the triads in Collingwood and Oakeshott is himself eager to establish something like a triadic view of the history of political thought. This is Boucher, who has not only written a book about Collingwood, and articles about Oakeshott, but a book about 'political theories of international relations.'21 This last book is evidently much used by scholars of international relations; but it is unlikely that many readers of the book have noticed its

20 Here, against Noel Malcolm, 'Oakeshott and Hobbes', in A Companion to Michael Oakeshott ed. Paul Franco and Leslie Marsh (Penn State University Press, 2012), pp. 217-31, it is necessary to say Oakeshott appears to recognise that Hobbes's political philosophy has a teleology. Malcolm ignores the threefold architectonic which prevents Oakeshott from ever doing anything as simple as associating his own theory, which is necessarily that of the third interpretation, with Hobbes's, which is that of the second. So when Malcolm comments, as if against Oakeshott, 'there was, underlying Hobbes's concept of the state, a substantive aim: peace', on p. 229, he is saying something Oakeshott certainly recognised. David Boucher, Political Theories of International Relations: From Thucydides to the Present (Oxford University Press, 1998). 
emphatically triadic structure. Boucher distinguishes three rival and to some extent successive traditions. He calls them:

1. The tradition of 'empirical realism': which he associates with Thucydides, Machiavelli, Marsilius and Hobbes.

2. The tradition of 'universal moral order': which he associates with the Stoics, Cicero, Christianity, Grotius, Pufendorf, Locke and Kant.

3. The tradition of historical reason: which he associates with Rousseau, Burke, Hegel, Marx, and almost everyone else since.

These are obviously Oakeshott's three traditions of reflection on politics, in turn derived from Collingwood's three successive views of nature. The only difference is that - perhaps for the sake of his own dialectic suggestion - Boucher reverses the order of the first and second. Boucher tells us that 'the traditions stand in dialectical relation to each other... ${ }^{22}$ The first involves the view that humans are 'radically subjective' autonomous creatures of sense, with their own interests, living in a world constituted by conflicts of interest. The second involves the view that humans are ruled by universal principles of justice. This is generally optimistic whereas the first is pessimistic: and it has a far closer relation to philosophy and theology than the first. ${ }^{23}$ These two are

antithetical; they are polar opposites. Realism postulates interest and expediency as criteria of state action, while the tradition of a Universal Moral Order postulates conformity to rule or principle: the former is a finite, empirical and pragmatic criterion; and the latter universal, generalised, and abstract. Each is one-sided in that it cannot accommodate the insights of the other, yet each has a positive value in over-emphasising an aspect of what motivates the actions of states. ${ }^{24}$

The third, Boucher tells us, overcomes the deficiencies of both. (Though I certainly think that it has its own difficulties: of which the major one is that almost every theory of the third type - except Hegel's, or perhaps even Hegel's! - is riddled with compromise. $)^{25}$ Boucher characterises the third by

\footnotetext{
22 Ibid., p. 23.

23 Ibid., pp. $29 \& 33$.

24 Ibid., p. 36.

25 For an exploration of this line of thought in a different context see my essay "The Fundamental Contradiction of Modern Cosmopolitanism' (forthcoming in European Legacy).
} 
saying that it involves the view that 'human nature is not a fixed entity'. All societies are 'historical societies.' ${ }^{26}$ Boucher finds this view originating in Vico, but finds it particularly applied to politics in Rousseau. He suggests that it is now ubiquitous: and he offers an interesting view of everyone up to and including Habermas and Rawls in these terms. "The same substantive end is desired by many political theorists of international relations: an extension of the moral community which posits a certain degree of universalism, while at the same time seeking to preserve difference and respect for diverse identities. ${ }^{27}$

I draw attention to the structure of Boucher's book because it would not be obvious to anyone not looking for it. Perhaps Boucher knows that few scholars would be able to accept it as a structuring hermeneutic, so he is inclined to present as much as possible as a finding which emerges out of consideration of countless texts. But from his other writings it is clear that Boucher is well aware of what he is doing.

In an article on Oakeshott, he quotes in appendix the entire passage from the introduction to Leviathan, and attempts to discover the extent to which Oakeshott used the triadic structure in his own writings. Boucher rightly notes that Oakeshott used it hardly at all. He argues, I think wrongly, that Oakeshott reserved the triad for thinking about 'masterpieces' of political philosophy, like those of Plato, Hobbes and Hegel, and not for 'political thought' as such..$^{28}$ This seems unlikely. It is more likely that Oakeshott simply thought the structure he found in Collingwood in 1945 a useful way of dramatising the significance of Hobbes when he came to write about him in 1946. There is hardly any sign in Oakeshott's lecture, and next to no sign in his published writings, that he thought it worth pressing the claim for this philosophy of political history any harder. It was simply an eminently thinkable suggestion, thrown up more or less casually: Oakeshott was clearly capable of such suggestiveness in his writings. And Boucher does rightly note that by the time Oakeshott came to write On Human Conduct he preferred to theorise in terms of two absolutely irreconcilable traditions (societas and universitas) rather than in terms of three traditions in which the third was to some extent, and no matter how loosely, a reconciliation of the first two. I see this as a sign of the declining Hegelian structure of Oakeshott's thought. Anyone who expresses himself in terms of an unreconciled dyad has certainly got a certain distance from Hegel.

Boucher rightly observes that others found more in the scheme than Oakeshott himself did: "This was a conception of the history of political

\footnotetext{
26 Boucher, Political Theories of International Relations, p. 37.

27 Ibid., p. 395.

28 Boucher, 'Oakeshott and the History of Political Thought', p. 79 ff.
} 
philosophy, with variations of one sort or another, that recommended itself to many adept followers of Oakeshott, foremost among whom [was] W.H. Greenleaf.'

Greenleaf himself suggest[ed] that T.D. Weldon characterised the first two traditions as the 'organic' and the 'mechanical' views of man; and Ernst Cassirer name[d] them 'intellectualism' and 'voluntarism'. In addition, Arthur Lovejoy recognise[d] them as the traditions of 'Otherworldliness' and 'Thisworldliness'; and Dante Germino, an admirer of Oakeshott, follow[ed] Jacques Maritain in referring to them as 'Theocentric Human' and 'Anthropocentric Humanism.29

But only Greenleaf attempted to make something of Oakeshott's threefold. In the 1970s he observed, rightly, that the history of political thought should not be 'a mere chronology of ideas'. So he followed Oakeshott in finding 'three styles of discussion' evident in the history of political thought, which should properly be thought of as 'a logically connected series of [three] paradigms': 'the relationship between them is that standards of the first two are, in principle, antithetical, while that initiated and addressed by Rousseau unites and completes both. 30

Apart from Greenleaf and Boucher, almost no one has made use of this scheme. There is evidence Oakeshott thought it would not work. ${ }^{31}$ I think Boucher, in his eagerness to make something of the scheme, does not say clearly enough that though the scheme may have seemed attractive to Oakeshott in 1946, it was no more than a suggestion proposed only for its suggestiveness, and which was forgotten by the time he came to write the book originally arranged by Collingwood for Oxford University Press but not published until 1975. Boucher is fond of suggesting that the triad was common to all idealists from Hegel through Bosanquet and Green to Oakeshott and Collingwood. ${ }^{32}$ To be sure, it is implicit in much: but it was not explicit until Oakeshott and Collingwood: who themselves soon dropped it, or at least interpreted it in

29 Ibid., p. 76.

$30 \quad$ W.H. Greenleaf, 'Hume, Burke and the General Will', Political Studies 20 (1972), 131-40, at p. 140. See also David Boucher, 'W.H. Greenleaf: Idealism and the Triadic Conception of the History of Political Thought', Idealistic Studies 16 (1986), pp. 237-52.

31 Boucher, 'Oakeshott and the History of Political Thought', p. 93, quoting a letter from Oakeshott.

32 David Boucher, The Social and Political Thought of R.G. Collingwood (Cambridge, 1989), p. 73 . 
different ways even when they advocated it. I will deal with Collingwood, to illustrate this point, in the next section. As far as Oakeshott is concerned, we must suppose that he thought that Hegelian reconciliation was no longer a suitable vehicle for his form of scepticism. Better than triads were dyads.

Dyads are still popular. Take Raymond Geuss, reflecting 'On the Very Idea of a Metaphysics of Right' in 2010. He supposes that we may see any interaction of humans in two ways, either as 'an instance of a set of rules, principles or formal procedures', or in terms of 'the motives, intentions and goals of the agents involved'. ${ }^{33}$ These are the first two terms of Oakeshott's scheme of 1946, as if the third does not exist, or is just a proper way of appreciating of the second. Historians of political thought have tended to be sceptical of all such schemes. Quentin Skinner reviewed Greenleaf's Order, Empiricism, Politics in 1966, and commented: 'If there are "traditions" of political thinking, they appear to be both richer and more confused than Dr Greenleaf's analysis can allow.' ${ }^{34}$ But this would apply to Geuss's scheme as well as Greenleaf's. And I think that although we have to acknowledge the force of Skinner's comment, we also have to recognise that if we thought it was the only truth then we would in effect be sanctioning only one half of what Plato in the Phaedrus thought was proper philosophical procedure: we would be collecting instances but not dividing the categories which enable us to make sense of those instances.

This might be all there was to say. But I want to add what might seem a digression about Collingwood's own political philosophy. This will enable us to say a bit more about the possible significance of finding patterns in history.

\section{The Oddity of Collingwood's Alternative Threefold Philosophy of Political History in New Leviathan (1942)}

Part of the claim here is that it is important to know if someone has a philosophy of political history. If they do, then it is necessary to understand this before one attempts to understand their political philosophy. So the scholastic question about whether Oakeshott owes more to Hegel or Hobbes is modified once we say that all the questions are secondary compared to his sense of their location in history. Oakeshott could not agree with Hobbes, since his philosophy of political history prevented him: quite simply we exist after the

33 Geuss, 'On the Very Idea of a Metaphysics of Right', Politics and the Imagination (Princeton: Princeton University Press, 2010), pp. 43-6o.

34 Quentin Skinner, 'On Two Traditions of English Political Thought' (a review of Greenleaf) Historical Journal 9 (1966), pp. 136-9, at p. 139. 
eighteenth-century arrival of a historical consciousness. Neither could he agree simply with Hegel: although agreement with Hegel is easier, since he wrote after the arrival of historical consciousness. He thought we are later, and different, and are in the condition of being able to see the traditions winding back behind us. We can no longer suppose that Hegel's reconciliations can work; even though it is true that his dialectic still offers us a compelling model of what a reconciliation might be if we thought the dialectic evident in history was susceptible to reconciliation, rather than, simply, to understanding in its fragments and contradictions.

Collingwood's philosophy of political history - the one evident in The New Leviathan, published in 1942, a few years before Oakeshott's 'Introduction to Leviathan' - is interesting because it indicates how Collingwood could propose a triadic scheme rather different from Oakeshott's. Collingwood's philosophy of political history was not a rendering of his history of his philosophy of nature into politics. Oakeshott stole from Collingwood; but Collingwood did not steal from Collingwood.

Before I begin, it should be noted that Collingwood was doing several things in The New Leviathan. One was to attempt to cover the same territory Hobbes had covered in Leviathan. A second was to put forward his own novel theory of utility, rules and duty. A third was to indicate why the Germans were barbarians. It is the fourth which is of relevance here. This was to propose three laws of politics, which were a summary of his reinterpretation of what he called, a bit confusingly, 'the classical politics'. By 'classical politics' he did not mean the politics of Plato and Aristotle; he meant the politics of Hobbes, Locke and Rousseau. And, unlike Oakeshott, who considered Hobbes the 'head and crown' of the second of three traditions, Collingwood considered Hobbes the creator of the third of three traditions. Hobbes was by far the toughest and most resourceful, as well as the most original, of the thinkers' he considered. ${ }^{35}$ In an unpublished draft preface he wrote that Leviathan was 'the first book in which the idea of a civilised society was consciously and systematically expounded' ${ }^{36}$ In the published preface Leviathan was 'the world's greatest store of political wisdom, ${ }^{37}$ Now, we cannot understand why unless we see where Hobbes came in Collingwood's philosophy of political history.

In order to understand Collingwood's philosophy of political history we have to understand his distinctive use of the terms 'society', 'community' and

\footnotetext{
35 R.G. Collingwood, The New Leviathan (Oxford: Clarendon Press, 1943), p. 261.

36 R.G. Collingwood, Essays in Political Philosophy ed. David Boucher (Oxford: Clarendon Press, 1989), p. 228.

37 Collingwood, The New Leviathan, p. lx.
} 
'non-social community'. In short, community is simply the entire social body, society is the part of the community which is capable of ruling itself - having achieved a requisite level of education or civilisation - and 'non-social community' is the part of that community which is not capable of ruling itself and therefore needs to be ruled by others. (Later in the book he calls them 'the herd', and suggests the German 'herd-worship' is a sign that Germans don't understand politics.) His philosophy of political history was in terms of the question 'What is the body politic?' This question had been answered in three ways at three different times.

First, as we might expect, were the Greeks, and also Romans. They thought that the body politic is society. For them, the polis was 'a society made up of citizens upon whom non-citizens were dependent.' ${ }^{38}$

Second, and this is Collingwood's novelty, were the writers of the Middle Ages. 'In the Middle Ages a body politic was conceived as a non-social community; ... a collective name for people born in a certain place. ${ }^{39}$

Third came Hobbes, Locke and Rousseau. It is worth quoting again one of the most arresting short passages ever written about politics. Here he is discussing what he called the account of a body politic given by 'the classical politics':

What is a body politic? Is it, as the Greeks believed, a society of citizens corporately ruling themselves and having non-citizen dependants, wives, children, and so forth? or is it, as the Middles Ages thought, a non-social community, a human herd which strong men rule and good men would wish to rule well?

Hobbes said: 'It is both.40

It is both because Hobbes was a dialectician, reconciling the two earlier views. 'The medieval account', continued Collingwood, 'represents the starting-point of the change, the Greek account the finishing-point. Between these two points it is always moving, and the movement is what constitutes the life of the body politic. 41

So, in short, Collingwood's philosophy of political history, also has three stages - stages, not traditions, since Collingwood tended always to be less cautious than Oakeshott in that respect - but it places Hobbes at the head of the

\footnotetext{
$38 \quad$ Ibid., p. 178.

39 Ibid., p. 179.

40 Ibid., p. 180.

41 Ibid., pp. 180-1.
} 
third, not the second. This, of course, means that Collingwood, perhaps surprisingly, did not talk very much about how the arrival of a historical consciousness affected political philosophy. It seems, perhaps, that he thought it did not. Or perhaps he had reason not to go into that particular matter in 1942. For the far more obvious thing about New Leviathan is the way Hegel is continually disparaged in comparison to Hobbes. If Oakeshott placed Hegel at the head of the third tradition, Collingwood simply has him as one of the Germans who more or less failed to understand the classical politics. Collingwood's relative playing down of Hegel is striking. He credited Plato with the invention of dialectic. ${ }^{42}$ Then he suggested that Hegel had misused the dialectic. And he claimed that Hobbes's conception of politics was dialectical. 'According to Hobbes (though Hobbes seems hardly to have recognised Plato's work on the subject) $a$ body politic is a dialectical thing: 43 This is quite remarkable. In Collingwood's threefold division in what I am calling his philosophy of political history, the third reconciliatory stage was granted not to Hegel but to Hobbes: and Collingwood went so far as to suggest that Hobbes in Leviathan, and not Hegel, achieved a dialectic resolution of politics.

In the chapter entitled 'The Classical Physics and the Classical Politics' Collingwood explored the relation between science as it was practiced by Galileo, Bacon, Descartes and Newton, and politics as it was understood by Hobbes. He contrasted this 'classical physics' with the understanding of science which existed at the time of Plato and Aristotle. The difference was, he suggested, that ancient science had an 'unlimited objective. 44 By this he meant that when an ancient scientist tried to define anything ('What is Nature?' 'What is Man?' 'What is Justice?') he sought to give a substantive definition of the thing, to capture its essence. But modern scientists since Galileo had attempted to have a limited objective'. They tried to avoid asking great and vague questions which could not be answered, and settled for discussing what could be measured or observed. In the same way, suggests Collingwood, 'the authors of the classical politics did not aim at explaining all political facts whatever': what they did instead was to only explain 'society' and not explain 'non-social community'. For them, this non-social community, which they called 'a state of nature' was a simple negation, a negation of the order which could be achieved in society. They sought 'to study the social elements in political life. 45

\footnotetext{
$42 \quad$ Ibid., pp. 181-2.

43 Ibid., p. 183.

44 Ibid., p. 253.

45 Ibid., p. 254.
} 
I do not have the inclination to go into why Collingwood was so hostile to the German philosophers. It is enough to say that he admired Hobbes for the open, unresolved dialectic: for Hobbes there was no reconciliation, only an endless dialectic between 'art' and 'nature', with art attempting to establish the 'classical politics' in the face of the continual possibility that 'society might break up into a non-social community'. 'We who no longer believe in a law of progress find it delightful after wading back through the bog of nineteenthcentury wish-fulfilment fantasies, that Hobbes did not believe in it either.'46 And on the Germans, he thought that part of the problem was their admiration for the original political theories of the Greeks: 'The revival of Greek philosophy by the German romanticists was in one thing at least a disaster: it gave the Germans (and their followers) what they mistakenly thought good authority for rejecting the classical politics; which in fact they rejected because, owing to their country's social and political backwardness, they could not understand it.'

Collingwood's account of German philosophy, and Hegel, in New Leviathan is interesting, if unfair. We can understand why he wrote it. But the major question must be why he ignored his own discovery in The Idea of Nature, which was that the view of science had been altered by an analogy with history in the eighteenth century: a revolution which could not be reversed. If this were true, then it is surely significant that he ignored this development in his political philosophy, and instead aligned the most advanced theory of politics with the physics of the seventeenth century. Admittedly, he wrote of the classical politics: 'Like the classical physics it can no longer be regarded as containing the last word about its subject.' But he also wrote: 'Not having found its Einstein it cannot be regarded as definitely superseded. ${ }^{47}$ In other words, Collingwood as the title of his book suggests - really thought that political philosophy should concern itself with minor adjustments to Hobbes's Leviathan, and that what I am calling here the philosophy of political history ended, in its major divisions, for the time being, with Hobbes (as adjusted, perhaps, by Collingwood). As Collingwood put it in his lectures in 1921: 'The task is to think on from Plato to Hobbes and then from Hobbes to something new which shall overcome the defects in Hobbes. 48

46 Ibid., p. 262.

47 Ibid., p. 247.

48 Quoted in Boucher, The Social and Political Thought of R.G. Collingwood, p. 67. 


\section{Conclusion: How We Have to Try to Make Sense of the Philosophy of Political History Before We Make Sense of Political Philosophy}

I have tried to show here that Oakeshott had a philosophy of political history, that it was a threefold, that he derived it from Collingwood's threefold philosophy of scientific history in Idea of Nature, even though Collingwood himself did not use it when putting forward his own threefold of politics in New Leviathan. The irony is that in The New Leviathan Collingwood suggested that there was an analogy between the 'classical physics' - by which he meant the natural science of the seventeenth century - and the 'classical politics' - by which he meant the political science of the seventeenth century, but that he himself in that book did not pursue the implication of his own argument of The Idea of Nature, which was that the natural science of the seventeenth century was a second paradigm which had been supplanted or supplemented by a third which emerged in the late eighteenth and early nineteenth centuries. Oakeshott did sometimes pursue this implication: first of all in the paragraph I have quoted, and which many other scholars quote, from the 'Introduction to Leviathan', and also in the lectures he gave in $1966-7$ and which were published for the first time in 2006. But it is hard to consider he made much of it. It is not in On Human Conduct, for instance. So, apart from revivals in Greenleaf and Boucher, these threefolds of the philosophy of political history have disappeared from view since the $1940 \mathrm{os}$.

One obvious reason might be that in offering a threefold history one can always disagree about the exact moment of reconciliation or the figure associated with it. Oakeshott in 1946 clearly thought Hegel was the reconciliatory figure; whereas a few years before Collingwood clearly thought it was Hobbes. But this is less important than the fact that Oakeshott and Collingwood both offered rival threefold philosophies of political history.

Oakeshott's philosophy of political history was:

1. Politics in history was first understood as something natural, because of an analogy between the mind of man and the mind of the universe, so that the mind of the universe flowed through the mind of man, so that science could enable us to understand politics just as it could understand nature, and did so because politics was natural to man: the polis was supposed to emerge naturally in human history and yet also be the telos of human activity.

2. Politics was then understood as something artificial, to be contrasted with the world of nature, the analogy now being the one between nature 
as God's creation and the various artifices of man's creation: which included the state. Since nature was separate from art, and since science could only tell us about nature, politics was not a science, or, if it was a science, it was the science of understanding the contingent and arbitrary, if practically necessary, decision made by humans to intervene in the world of nature to create an artificial order called political.

3. Politics was finally understood as something historical, neither to be contrasted with nature, nor to form a continuity with it, but to be in some way both artificial and natural: here the analogy was between nature as having a mutable changeable history and politics as having a mutable changeable history; so that politics and the state were historical emergences, neither wholly matters of art or of nature, but of historic experience, usually dependent on decisions wholly lost in time and established only in our traditions and subsequent criticisms of them, and the traditions which emerged as criticism had a dialectical effect on the original traditions.

Collingwood's philosophy of political history was:

1. Politics was first understood as only concerning the citizens of the city: where the citizens were those who could rule themselves, and leaving all others out of account.

2. Politics was then understood as concerning all of the inhabitants of the state: where all of these inhabitants were included in politics and considered to be in need of being ruled.

3. Politics was finally understood as somehow both concerning those who can rule themselves and those who are in need of rule: 'It is both'. It is the means by which those who cannot rule themselves relate to those who rule in such a way that they are continually educated into a position where they can actually or ideally rule themselves, though we are not to expect that this education will ever cease or ever be completed. In this sense the first understanding is the end of politics, and the second is the beginning.

Oakeshott associated his threefold with
1. Plato,
2. Hobbes and
3. Hegel, 
while Collingwood associated his threefold with
1. Plato,
2. the Middle Ages and
3. Hobbes.

What both philosophies of history had was the suggestion that the third of the three was a dialectical reconciliation of the first two, though incomplete. Collingwood's was simpler, and far more ingenious: far more original, though also far more questionable, for the reason that he supposed that his threefold formed stages or moments, whereas Oakeshott supposed that his formed traditions. Collingwood thought that, politically speaking, the nineteenth century had involved an error, and that in the future it was necessary to return to the 'classical politics' of the seventeenth century. Ironically, he did this by making Hobbes the culmination of a dialectical history. This was a Hegelian history with Hobbes and not Hegel as its central character. Oakeshott, on the other hand, kept Hegel as the culmination, but put a question mark against the view that it was anything other than an apparently philosophical culmination, and himself seems to have preferred the view that in a contestation of rival traditions there was no winner in history, least of all Hegel. This was a Hegelian history which, in transcending Hegel, also indicated that there was good reason to consider Hobbes seriously and not consider him historically outmoded. On that point - the point that Hobbes should be taken seriously - both men were agreed. And on the other point - that some sort of philosophy of political history was a contribution to understanding, and that it should take dialectical form - both men were agreed.

Now, we may well ask why Hobbes and Hegel are so significant for both Collingwood and Oakeshott. This is related to a question we should ask ourselves, which is why Hobbes and Hegel should be significant for us. The answer is that if we know both Hobbes and Hegel - and not just one of them (the weakness of Skinner is his lack of appreciation of Hegel, the weakness of Taylor is his lack of appreciation of Hobbes) - is that Hobbes brings to consciousness (in the opening pages of De Cive alone, but of course throughout the pages of Leviathan) that consciousness, meaning his consciousness but also, he supposed, and we may suppose rightly, our consciousness was shifting from an older to a newer stage (if we prefer the Collingwoodian view) or forcibly contrasting a second tradition with a first (if we prefer the Oakeshottian view); and that Hegel brings to consciousness the fact that the Hobbesian position was incomplete for the historical reason that history did not end in 1651 and for the 
philosophical reason that the rivalry between these two traditions was so radical it required, at the very least, further thought and, it was to be hoped, some sort of means by which they could be reconciled. Hobbes makes it clear to us that the classical tradition had not closed all questions and Hegel made it clear to us that the challenge to the classical tradition had itself not closed all questions. This way of seeing the philosophy of political history is so cumulatively powerful - even if we do not think, as Hegel did, that resolution was possible (and we may, of course, disagree with Hegel for historical or for philosophical reasons) - that we can see why Oakeshott thought that those who understood Hegel could be excused their belief that in the nineteenth century all the riddles of the seventeenth century $\mathrm{AD}$ and the fourth century BC had been resolved. We know better: as Collingwood and Oakeshott did. But reflection on politics, if it is to involve reflection on history and philosophy, must, I think, begin with understanding the fact that the history of political philosophy is not a meaningless or arbitrary set of reflections on miscellaneous experiences but is, in great measure, a philosophy of political history which can be unravelled, seen as a whole, and admired and lamented for what it has left us with in our twenty-first century.

It is still rare to see explicit philosophies of political history. I think there should be more. The one sketched here has found a few adherents, even in unexpected places. It is possible that Bobbio was influenced by Oakeshott in his book Thomas Hobbes and the Natural Law Tradition, where he described the history of political philosophy in terms of three 'tracks', the first of which was 'Aristotelian', the second 'Hobbesian', the third 'Hegelian'.

The Hegelian system is so inclusive as to leave out nothing essential of the previous systems ... until Hegel, the whole tradition of political philosophy proceeded on two parallel tracks: the Aristotelian track, based on the pair family/state; and the Hobbesian track, based on the pair state of nature/civil society, Hegel is the first (and last) to merge the two models in his system ... He can perform this operation because he articulates his system in triads rather than pairs. ${ }^{49}$

The addition Bobbio makes is to suggest that Hegel was both first and last to do this. The point is not that we should imagine this philosophy of history as a succession of stages, but rather as an intertwining of traditions in which certain great recognitions are historically foundational for what comes afterwards. 
In this sense, they are 'events' in Zizek's or Badiou's sense: ruptures in the history of political philosophy, which not only condition everything which comes afterwards but everything which came before. Zizek in his recent book Event suggested that the 'three (and only three) key philosophers in the history of Western metaphysics' were Plato, Descartes and Hegel..$^{50}$ But since, as Tuck put it, Descartes was 'one of the few major philosophers never to write on politics, ${ }^{51}$ it is important to recognise the power of the claim that the three key philosophers in the history of Western political philosophy were Plato, Hobbes (Descartes's great contemporary and rival), and Hegel. This philosophy of political history could and certainly should be characterised further.

In addition, alternatives could be explored. There is no reason to limit ourselves to Plato, Hobbes and Hegel. Other lineages could be explored. Al-Khidr, Moses and Aristotle, perhaps. Or Lao-Tzu, Confucius and Montesquieu. And others could be admitted. There are many recent writers who probably hoped they would be a third in a dialectical threefold of which the first two elements were Rawls and Nozick. And probably now some even more recent writers would prefer to ignore Nozick, and instead consider Rawls and one of these other writers the first two elements of a triad including themselves, so we would have Rawls, Sandel and a third, Rawls, Sen and a third, Rawls, Cohen and a third, or even now Rawls, Geuss and a third. Admittedly, these might be fairly poor ones. Yet every triad would suggest a novel axis for a possible philosophy of political history. (Though the more modern the figures named, the poorer any philosophy of political history would be as history.) The point is that we have philosophies of political history whether we know it or not: sometimes very poor ones. Political philosophy would benefit from a slightly clearer consciousness about this fact. Philosophies of political history should be admitted, identified, even encouraged. They would enable us to recognise the reflexive relation we all have to the entire canon, or set of canons, as they now increasingly are. I think this sort of recognition is a precondition of saying anything at all valuable in political philosophy.

Nothing dogmatic should follow from this. I noted earlier that the first word of Oakeshott's paragraph is a conditional 'If', and this is why we may consider the philosophy of political history to be a completely open form. This sort of philosophy of history imposes nothing final on history. For every philosophy of history depends on an axis of conditionality - including, it should be obvious, Oakeshott's.

50 Slavoj Zizek, Event: Philosophy in Transit (London: Penguin, 2014), p. 77.

$5^{1}$ Richard Tuck, Hobbes (Oxford University Press, 1989), p. 20. 